\title{
Outcome of Patients Having Acute Myocardial Infarction with and without Streptokinase
}

\author{
Faruque Uddin *1, AK Fazlul Hoque ${ }^{2}$
}

\section{Abstract}

Introduction: Acute myocardial infarction is the leading cause of death. Streptokinase is the most commonly used thrombolytic agent. This study was conducted to compare in-hospital outcome of patients with acute myocardial infarction receiving streptokinase with those not receiving it. Materials \& Methods: This descriptive observational study was conducted at Coronary Care Unit, North East Medical College Hospital from 1st July August 2016 to 30 th June 2018. 340 patients having acute MI were in-cluded in the study. Two groups were formed: sk group receiving streptokinase and non-sk group not receiving. In-hospital mortality was the primary end point while mechanical and electrical complications were the secondary end points. Results: Among 340 patients, 255(75\%) were males and 85(25\%) females. Out of those 218 received strep-tokinase, while 122 did not. Mean age of sk group was 53.15 10.30 years and non-sk group $60.5 \pm 16$ ears. Mean time of arrival to the hospital after symptom onset was $10.41 \pm 9.97$ hours. SK group patients reached in 5.9 \pm 4.76 hours while non-sk group in 19.4 \pm 10.5 hours. In-hospital mortality in sk and non-sk group was $19(8.7 \%)$ and $25(20.5 \%)$ respectively, $p=0.002$. Complication rate was significantly higher in the non-sk group, 54.09\% vs $34.86 \%, p=0.04$. Conclusion: Patients of acute myocardial infarction receiving streptokinase have significantly lesser in-hospital mortality and complications as compared to patients not receiving it.

Keywords: Acute Myocardial Infarction, Streptokinase, In-Hospital Mortality.

Number of Tables: 03; Number of References: 20; Number of Correspondences: 02

*1. Corresponding Author:

Dr. Faruque Uddin

MBBS, D-Card, MD (Cardiology)

Professor and Head

Department of Cardiology

North East Medical College

Sylhet, Bangladesh.

E-mail: Mduddin.faruk@gmail.com

2. Dr. AK Fazlul Hoque

Associate Professor

Department of Cardiology

North East Medical College, Sylhet.

\section{Introduction}

Acute myocardial infarction (AMI) is the leading cause of death ${ }^{1}$. Myocardial infarction results from prolonged myocardial ischemia precipitated in most cases by rupture of the pre-existing plaque leading to occlusive thrombus formation in the coronary artery ${ }^{2}$. The introduction of coronary care units decreased Acute MI mortality from $30 \%$ to $15 \%$, while the use of thrombolytics further de- creased it to $5-7 \%{ }^{3}$. Prompt reperfusion of the occluded artery through Percutaneous coronary angioplasty or thrombolytic therapy decreases the duration of occlusion leading to improved mortality ${ }^{4}$.
Streptokinase (SK) is the most tested and commonly used thrombolytic worldwide because of its widespread availability and ability to reduce morbidity and mortality ${ }^{5-7}$.

Despite abundant evidence in support of use of thrombolytics, approaches in its use still vary with a large number of patients still failing to receive any form of reperfusion ${ }^{8}$. It is partly related to delay in presentation after the onset of symptoms. The effectiveness of fibrinolytic treatment is inversely correlated with the time from the onset of chest pain to the beginning of therapy ${ }^{9}$, there is overwhelming evidence of benefit if it is given within first hour of symptom onset, with loss of benefit over time?

In Bangladesh in-hospital outcome of acute MI patients treated with streptokinase has been studied in various centers ${ }^{10-13}$, but so far no such data is available for peripheral hospital.

We designed this study to compare the in- hospital outcome of acute MI patients receiving SK with those not receiving.

\section{Materials and Methods}

This study was conducted at Coronary Care Unit, North East Medical College Hospital from 1st July August 2016 to 30th June 2018. Three hundred \& forty patients were included, diagnosed as having AMI on the basis of WHO criteria. Patients presenting with Non- ST elevation MI were excluded.

The study population was divided into two groups:

1. Patients receiving streptokinase after exclusion of any contraindication.

2. Patients not receiving streptokinase because of either late presentation or the presence of any contraindication. 
Observation regarding age, gender, occupation, address, history of smoking, diabetes mellitus, hypertension, family history of ischemic heart disease and time from the symptoms onset to the hospital arrival was noted on a preformed Proforma. Thorough physical examination was carried out in all the patients. Complete blood count, fasting blood sugar, CK-MB level, serum urea, creatinine, lipid profile, chest X-ray and serial ECG's were carried out in all patients. Echocardiography was performed to look for left ventricular ejection fraction and any mechanical complications. All patients were treated as per CCU protocol ${ }^{14}$. Patients were followed till the discharge or death. In- hospital mortality was the primary end point while the developments of complications during the hospital stay were the secondary end points of the study.

All data was analyzed using Statistical Package for Social Sciences version 11.0. Student $\mathrm{t}$ test was applied to analyze continuous variables while chi-square test for the categorical ones.

\section{Results}

In 340 patients with Acute MI, 218 (64.11\%) were in SK group and $122(35.88 \%)$ in the non-SK group. For baseline characteristics in Table-I. No difference of statistical significance was observed between the two groups.

Table-I: Demographic variables of the patients.

\begin{tabular}{lccc}
\hline \multicolumn{1}{c}{ Characteristics } & $\begin{array}{c}\text { SK group } \\
(\mathbf{N}=\mathbf{2 1 8})\end{array}$ & $\begin{array}{c}\text { Non SK } \\
\text { group } \\
(\mathbf{N = 1 2 2})\end{array}$ & $\begin{array}{c}\text { Total } \\
(\mathbf{N}=340)\end{array}$ \\
\hline Age (years) Mean & $53.15 \pm 10.3$ & $60.50 \pm 16.00$ & $55.79 \pm 13.11$ \\
$<45$ years & $59(27.1 \%)$ & $29(23.8 \%)$ & $88(25.9 \%)$ \\
45-55 years & $71(32.6 \%)$ & $32(26.2 \%)$ & $103(30.3 \%)$ \\
$<55$ years & $88(40.4 \%)$ & $61(50.0 \%)$ & $149(43.8 \%)$ \\
\hline Gender Male & $168(77.1 \%)$ & $87(77.3 \%)$ & $255(75.0 \%)$ \\
$\quad$ Female & $50(22.9 \%)$ & $35(28.7 \%)$ & $85(25.0 \%)$ \\
Diabetes Mellitus & $79(36.2 \%)$ & $59(48.4 \%)$ & $138(40.6 \%)$ \\
Hypertension & $80(36.7 \%)$ & $46(37.7 \%)$ & $126(37.1 \%)$ \\
Smoking & $133(61 \%)$ & $69(56.6 \%)$ & $202(59.4 \%)$ \\
Family history of IHD & $74(33.9 \%)$ & $39(32.0 \%)$ & $113(33.2 \%)$ \\
\hline
\end{tabular}

In table II- Mean time of arrival to the hospital after symptom onset was $10.41 \pm 9.97$ hours. Patients in sk group presented earlier than non-sk group, 5.9 \pm 4.76 hours' vs $19.39 \pm 10.53$ hours. In non-sk group 16 (13.1\%) had contraindication to thrombolytic therapy Overall in-hospital mortality was $44(12.9 \%)$, with more deaths among patients in non-sk group $25(20.5 \%)$ as compared to $19(8.7 \%)$ in sk group $(\mathrm{p}=0.002)$.

Table-II: Characteristics of patients at presentation.

\begin{tabular}{llll}
\hline $\begin{array}{l}\text { Presentation } \\
\text { characteristics }\end{array}$ & $\begin{array}{c}\text { SK Group } \\
(\mathbf{n}=\mathbf{2 1 8})\end{array}$ & $\begin{array}{c}\text { Non SK Group } \\
(\mathbf{n}=\mathbf{1 2 2})\end{array}$ & $\begin{array}{c}\text { Total } \\
(\mathbf{n}=340)\end{array}$ \\
\hline $\begin{array}{l}\text { Duration of } \\
\text { chest pain }\end{array}$ & $5.9 \pm 4.76$ & $19.39 . \pm 10.53$ & $10.41 \pm 9.97$ \\
\cline { 2 - 4 } (hours) Mean & $65(29.8 \%)$ & $2(1.6 \%)$ & $67(19.7 \%)$ \\
$<3$ hours & $100(45.9 \%)$ & $5(4.1 \%)$ & $105(30.9 \%)$ \\
3-6 hours & $34(15.6 \%)$ & $9(7.4 \%)$ & $43(12.6 \%)$ \\
6-12 hours & $19(8.7 \%)$ & $106(86.9 \%)$ & $125(36.8 \%)$ \\
$>12$ hours & & &
\end{tabular}

\begin{tabular}{|c|c|c|c|}
\hline $\begin{array}{l}\text { Presentation } \\
\text { characteristics }\end{array}$ & $\begin{array}{l}\text { SK Group } \\
(n=218)\end{array}$ & $\begin{array}{c}\text { Non SK Group } \\
\quad(n=122)\end{array}$ & $\begin{array}{c}\text { Total } \\
(\mathrm{n}=\mathbf{3 4 0})\end{array}$ \\
\hline \multicolumn{4}{|l|}{ ECG } \\
\hline Anterior wall MI & $129(59.2 \%)$ & $73(59.8 \%)$ & $202(59.4 \%)$ \\
\hline Inferior wall MI & $77(35.3 \%)$ & $39(32.0 \%)$ & $116(34.1 \%)$ \\
\hline Posterior wall MI & $8(3.7 \%)$ & $4(3.3 \%)$ & $12(3.5 \%)$ \\
\hline Lateral wall MI & $3(1.4 \%)$ & $5(4.1 \%)$ & $8(2.4 \%)$ \\
\hline LBBB & $1(0.5 \%)$ & $1(0.8 \%)$ & $2(0.6 \%)$ \\
\hline $\begin{array}{l}\mathrm{CK}-\mathrm{MB} \\
\text { mean }(\mathrm{U} / \mathrm{I})\end{array}$ & $199.9 \pm 126.7$ & $168.6 \pm 85.87$ & $186.6 \pm 114.6$ \\
\hline $\begin{array}{l}\text { Serum urea } \\
\text { mean }(\mathrm{mg} / \mathrm{dl})\end{array}$ & $32.6 \pm 21.5$ & $47 \pm 64.6$ & $41 \pm 27.3$ \\
\hline $\begin{array}{l}\text { Serum } \\
\text { Creatinine mean } \\
(\mathrm{mg} / \mathrm{dl})\end{array}$ & $0.99 \pm 0.35$ & $1.26 \pm 0.87$ & $1.06 \pm 0.60$ \\
\hline
\end{tabular}

In table-III Complication rate was higher in non-sk group as compared to sk group, $\mathrm{p}=0.046$. LVF was the most common complication $70(20.6 \%)$, it was also the leading cause of death in both the groups; $13(6 \%)$ in sk group and $13(10.7 \%)$ in non-sk group, $\mathrm{p}<0.0001$. VT/VF was the second most common complication $26(7.6 \%)$ and the cause of death in $3(1.4 \%)$ patients in sk and $5(4.1 \%)$ in non-sk group, $\mathrm{p}<0.0001$. Post $\mathrm{MI}$ angina occurred in 11 $(5 \%)$ of cases in sk group as compared to $11(9 \%)$ in non-sk group but was not statistically significant, $\mathrm{p}>0.05$.

Table-III: In-Hospital outcome of patients with and without streptokinase.

\begin{tabular}{lllll}
\hline Outcome measure & $\begin{array}{c}\text { SK Group } \\
(\mathbf{n = 2 1 8})\end{array}$ & $\begin{array}{c}\text { Non SK } \\
\text { Group } \\
(\mathbf{n = 1 2 2})\end{array}$ & $\begin{array}{c}\text { Total } \\
(\mathbf{n = 3 4 0})\end{array}$ & $\begin{array}{c}\text { P } \\
\text { value }\end{array}$ \\
\hline In-Hospital mortality & $19 .(8.7 \%)$ & $25 .(20.5 \%)$ & $44 .(12.9 \%)$ & 00.2 \\
\hline Cause of death & & & & \\
Left ventricular failure & $13(6.0 \%)$ & $13(10.7 \%)$ & $26(7.6 \%)$ & \\
Asystole & $1(0.5 \%)$ & $3(2.5 \%)$ & $4(1.2 \%)$ & 0.046 \\
VT/VF & $3(1.4 \%)$ & $5(4.1 \%)$ & $8(2.4 \%)$ & \\
CHB & $2(0.9 \%)$ & $3(2.5 \%)$ & $5(1.5 \%)$ & \\
\hline Complications & $76(34.86 \%)$ & $66(54.09 \%)$ & $142(41.76)$ & 0.040 \\
\hline Left ventricular failure & $39(17.9 \%)$ & $31(25.4 \%)$ & $70(20.6 \%)$ & \\
Mitral regurgitation & $3(1.4 \%)$ & $2(2.5 \%)$ & $5(1.5 \%)$ & \\
VT/VF & $136.0 \%)$ & $13(10.7 \%)$ & $26(7.6 \%)$ & \\
Complete heart block & $7(3.2 \%)$ & $4(3.3 \%)$ & $11(3.2 \%)$ & \\
Atrial fibrillation & 0 & $1(0.8 \%)$ & $1(0.3 \%)$ & \\
Post MI angina & $11(5.0 \%)$ & $11(9.0 \%)$ & $22(6.5 \%)$ & \\
Re-infarction & 0 & $2(1.6 \%)$ & $2(0.6 \%)$ & \\
CVA & $1(0.5 \%)$ & 0 & $1(0.3)$ & \\
Ventricular septal defect & $2(0.9 \%)$ & $2(1.6 \%)$ & $4(1.2 \%)$ & \\
\hline
\end{tabular}

\section{Discussion}

Acute myocardial infarction still remains the leading cause of death despite recent advances in its management. SK is the most commonly used thrombolytic agent worldwide. In our study the in-hospital mortality of patients with Acute MI was $8.7 \%$ in thrombolysed group and $20.5 \%$ in non-thrombolysed group. Our results are consistent with the previous studies ${ }^{5,9-11,15}$. In ISIS-2 the in-hospital mortality was $8 \%$ in patients receiving re perfusion as compared to $13 \%$ in the non-reperfused group 5 . Data from WIRE registry ${ }^{9}$ showed in-hospital mortality of $9.25 \%$ in sk group which is also similar to our results. Ahmed et al ${ }^{10}$ 
reported in-hospital mortality of $10 \%$ and $19.56 \%$ in the thrombolysed and non-thrombolysed groups. In-hospital mortality in ISIS-3 trial $^{15}$ was $10.5 \%$ and $10.4 \%$ in the anistreplase and streptokinase group respectively. In-hospital mortality reported in Khurram et $\mathrm{al}^{11}$ and French Regitary ${ }^{16}$ was $11.5 \%$ and $9.3 \%$, while data from GRACE ${ }^{17}$ trial showed in-hospital mortality of $7 \%$, which is lower than observed in our study. The reason for low mortality in GRACE study could be that $43 \%$ patients received lytic therapy alone while $57 \%$ lytic and $\mathrm{PCI}$, while in our study the only reperfusion agent available was sk, which can explain the better results achieved in that trial. Complication rate in our study was higher in non-sk group $(54.09 \%)$ as compared to sk group $(34.86 \%)$. LVF was the most common complication which occurred in $17.9 \%$ sk vs $25.4 \%$ non-sk group. These findings are consistent with the previous study ${ }^{18}$. In our study VT/VF occurred in $7.6 \%$ patients while in Tebbe et $\mathrm{al}^{19}$ it was $26.9 \%$. It was the second leading cause of death in our study occurring in $1.4 \%$ thrombolysed patients as compared to $4.1 \%$ non-thrombolysed patients.

A total of $64.11 \%$ patients in our study got reperfusion therapy which was similar to reported by other studies such as $68.3 \%, 52.08 \%, 68 \%, 47 \%$ and $62 \%$ in WIRE registry ${ }^{9}$, Ahmed et $\mathrm{al}^{10}$, Habib et $\mathrm{al}^{12}$, Chaudhery et $\mathrm{al}^{13}$, and GRACE $^{17}$ respectively.

More patients in our study presented within six hours of symptom onset in the SK receiving group than in the non-sk group (75.7\% vs 5.7\%). Gurwitz et al ${ }^{20}$ reported $40 \%$ of patients presenting to hospital six hours after symptoms onset as compared to $49.4 \%$ in our study. Patients in our study reported earlier to the hospital after symptom onset than reported by Habib et $\mathrm{al}^{12}$, mean time of arrival $10.41 \pm 9.97$ hours' vs 12.4 hours by Habib et al. All the $32 \%$ patients who failed to receive thrombolysis presented after 6 hours in study by Habib et al ${ }^{12}$ while in our study $94.3 \%$ patients in the non-sk group presented after 6 hours of symptoms onset. In our study 13.1\% patients had contraindications to thrombolysis which was comparable with $15 \%$ reported in WIRE registry ${ }^{9}$. Patients in our study had equal chance of receiving streptokinase; patients in non- thrombolysed group either presented late or had some contraindication to thrombolysis.

\section{Conclusion}

Patients with acute myocardial infarction receiving streptokinase have significantly lesser in- hospital mortality and post MI complications as compared to those not receiving it.

Conflict of Interests: None.

Acknowledgement

This research could not have been conducted without the permission and support of North East Medical College hospital authorities and staffs of coronary care unit.

\section{References}

1. Gershlick AH. Acute management of myocardial infarction. Medicine. 1997; 25: 62-7.

2. Boersma E, Mercado N, Poldermans D. Acute myocardial infarction. Lancet. 2003; 361: 847-56.

https://doi.org/10.1016/S0140-6736(03)12712-2

3. Waeber B. Review, Treatment Strategy to Control Blood Pressure optimally in hypertensive patients, Blood Press. 2001; 10: 62-73.

https://doi.org/10.1080/08037050152112041

PMid:11467762

4. The GUSTO Angiographic Investigators. The effects of tissue plasminogen activator, streptokinase, or both on coronary-artery patency, ventricular function, and survival after acute myocardial infarction. N Engl J Med. 1993; 329: 1615-22. [Erratum, N Engl J Med 1994; 330:516.]

https://doi.org/10.1056/NEJM199311253292204

PMid: 8232430

5. Effectiveness of intravenous thrombolytic treatment in acute myocardial infarction. Gruppo Italiano per lo Studio della Streptochinasi nell'Infarto Miocardico (GISSI). Lancet. 1986; 1: 397-401.

6. ISIS-2 (Second International Study of Infarct Survival) Collaborative Group. Randomised trial of intravenous streptokinase, oral aspirin, both, or neither among 17187 cases of suspected acute myocardial infarction: ISIS-2. Lancet 2: 349-60.

7. Fibrinolytic Therapy Trialists (FTT) Collaborative Group. Indications for fibrinolytic therapy in suspected acute myocardial infarction: collaborative overview of early mortality and major morbidity results from all randomised trials of more than 1000 patients. Lancet. 1994; 343: 311-22.

https://doi.org/10.1016/S0140-6736(94)91161-4

8. French WJ. Trends in acute myocardial infarction management: use of the National Registry of Myocardial Infarction in quality improvement. Am J Cardiol. 2000; 85: 5-9. https://doi.org/10.1016/S0002-9149(00)00752-9

9. Grajek S, Lesiak M, Araszkiewicz A, Pyda M, Skorupski W, Grygier M, et al. Short and long-term mortality in patients with ST-elevation myocardial infarction treated with different therapeutic strategies. Results from WIelkopolska Regional 2002 Registry (WIRE Registry). Kardiol Pol. 2008; 66: 154-63.

10. Ahmed S, Qureshi MBA, Abbas MZ, Chaudhry MK, Ghani MU. A comparative study of complications in patients of Myocardial Infarction managed with and ithout treptokinase. Pak J Cardiol. 2004; 15: 61-7.

11. Khurram M, Khaar HB, Javed S, Hasan Z, Goraya F, Haq UU. Acute Myocardial Infarction: Experience at a Teaching Hospital. J Rawal Med Coll. 2002; 6: 65-9.

12. Habib S, Noor A, Madni A, Zaman KS. Delays in thrombolytic therapy among patients with ST- Elevation myocardial infarction presenting to ter- tiary care hospital. Pak J Cardiol. 2006; 17: 29-39. 
13. Chaudhry AH, Pirzada MA, Amin K, Shaukat A. Acute myocardial infarction; study of in-hospital complications in patients treated with streptokinase versus control. Professional. 2000; 67: 213-20.

14. Antman EM, Hand M, Armstrong PW, Bates ER, Green LA, Halasyamani LK, et al. Focused Up-date of the ACC/AHA 2004 Guidelines for the Management of Patients with ST-Elevation Myo- cardial Infarction. Circulation. 2008; 117: 296-329.

https://doi.org/10.1161/CIRCULATIONAHA.107.188209 PMid: 18071078

15. ISIS-3: a randomised comparison of streptokinase vs tissue plasminogen activator vs anistreplase and of aspirin plus heparin vs aspirin alone among 41,299 cases of suspected acute myocardial infarction. ISIS-3 (Third Inter-National Study of Infarct Survival) Collaborative Group. Lancet. 1992; 339: 753-70.

https://doi.org/10.1016/0140-6736(92)91893-D

16. Danchin N, Blanchard D, Steg PG. USIC 2000 investigators. Impact of prehospital thrombolysis for acute myocardial infarction on 1- year outcome: results from the French Nation- wide USIC 2000 Registry. Circulation. 2004; 110: 1909-15.

https://doi.org/10.1161/01.CIR.0000143144.82338.36

PMid: 15451803
17. Steg PG, Goldberg RJ, Gore JM. GRACE Investigators. Baseline characteristics, management practices, and in-hospital out- comes of patients hospitalized with acute coronary syndromes in the Global Registry of Acute Coronary Events (GRACE). Am J Cardiol. 2002; 358-63. https://doi.org/10.1016/S1062-1458(02)00900-5

18. Mahon NG, O?Rorke C, Codd MB, McCann HA, McGarry K, Sugrue DD. Hospital mortality of acute myocardial infarction in the thrombolytic era. Heart. 1999; 81: 478-82.

https://doi.org/10.1136/hrt.81.5.478

PMid:10212164 PMCid:PMC1729025

19. Tebbe U, Michels R, Adgey J, Boland J, Caspi A, Charbonnier B, et al. Randomized, Double-Blind Study Comparing Saruplase with Streptokinase Therapy in Acute Myocardial Infarction: The COMPASS Equivalence Trial. J Am Coll Cardiol. 31: 487-93. https://doi.org/10.1016/S0735-1097(97)00553-6

20. Gurwitz JH, McLaughlin TJ, Willison DJ, Guadagnoli E, Hauptman PJ, Gao X, et al. Delayed Hospital Presentation in Patients Who Have Had Acute Myocardial Infarction. Ann Intern Med. 1997; 126: 593-9. https://doi.org/10.7326/0003-4819-126-8-199704150-00001 PMid:9103125 